\title{
The Sexton of Copenhagen
}

A couple of reflections on Kierkegaard's conception of language

\author{
Jacob Bøggild \\ University of Copenhagen \\ Søren Kierkegaard Research Centre
}

$\begin{array}{ll}\text { HAM LET. } & \text { How came he mad? } \\ \text { FIRST CLOWN. } & \text { Very strangely, they say. } \\ \text { H AM LET. } & \text { H ow strangely? } \\ \text { FIRST CLOWN. } & \text { Faith, e'en with losing his wits. } \\ \text { H AM LET. } & \text { U pon what ground? } \\ \text { FIRST CLOWN. } & \text { Why, here in D enmark. }\end{array}$

$\mathrm{H}$ amlet, of course, is a play in which death holds centre stage. But the name of Søren Kierkegaard is also charged with death to a disturbing degree.

M ost of Søren Kierkegaard's siblings died at an early age, which convinced M ichael Pedersen Kierkegaard, Søren's father, that G od was punishing him for his sins by making him survive all his children. He shared this morbid fantasy with Søren, who was therefore certain that he would die before he turned 33. So when K ierkegaard actually did reach this age, it was to his own complete surprise, even though his father had in fact died by then.

K ierkegaard's first longer work in prose, From the Papers of $O$ nestill Living, was written well before his 33th birthday, but its title might still convey his idea of being a survivor of sorts, a person living on borrowed time ${ }^{1}$. In this text, Kierkegaard also launches hisidea that the genuine author must be «dead», meaning that he must know to keep his own personal conflicts apart from what he is writing. Later on, in the first part of Either-O $r$, we are introduced to a whole society of such aesthetically "buried lives", namely the Symparane kromenoi ${ }^{2}$. And if we move from aesthetics to religion, the true Christian,

1. In the fictive framework of the text, however, this person who is still alive is a kind of pseudo-pseudonym, whose papers has been published against his will by a certain $\mathrm{S}$. Kierkegaard.

2. Several of the essays in the first part of Either-O $r$ are lectures or speeches addressed to this society. The most interesting one of these is the essay on ancient and modern tragic drama. I have written an article about this essay, «T he FineArt of W riting Posthumous Papers», which has been published in Kierkegaardiana, 19 (C openhagen, 1998). 
according to Kierkegaard's theology, is likewise a dead character, namely a person who is dead to the world.

M oreover, in D anish Kierkegaard's surname literally means churchyard. of course, one could easily argue that what accidentally takes place at such a basic level of language is of no philosophical or theoretical relevance. But the «first clown» of Shakespeare's H amlet, the sexton digging 0 phelia's grave, would certainly argue otherwise. In fact, $\mathrm{H}$ amlet, no mean manipulator of language, in the beginning of the fourth act of the play meets his match in the shape of this sexton, who insists on the very literality of the letter. 0 ne might even say that it is $\mathrm{H}$ amlet, the intentional or autonomous subject, who is getting buried. All of $\mathrm{H}$ amlet's speech acts are absorbed or annulled by the black hole of the sexton's rhetoric. So when $\mathrm{H}$ amlet addresses the following aside to H oratio: «H ow absolute the knave is! We must speak by the card, or equivocation will undo us», it is highly ironic, as the sexton aptly demonstrates the impossibility of speaking «by the card», of avoiding equivocation. Language is permeated by dead metaphors (like «upon what ground ?») and therefore everyone using it risks feeling the impact of such a sexton's spade. I will venture to argue that Kierkegaard was well aware of this fact and that he, as befits his name, was no mean linguistic sexton himself. Alas, it will be impossible for me to address all of K ierkegaard's oeuvre here. Instead, I will concentrate on two short passages from his works, one from his dissertation on irony, The Concept of Irony, and one from The Concept of Anxiety, alledgedly written by the pseudonym Vigilius $\mathrm{H}$ aufniensis, "The watchman of C openhagen".

In The Concept of I rony, Kierkegaard offers the following allegorical example of the way irony works:

There is an engraving that portrays the grave of $\mathrm{N}$ apoleon. Two large trees overshadow the grave. There is nothing else to be seen in the picture, and the immediate spectator will see no more. Between these two trees, however, is an empty space, and as the eye traces out its contour $\mathrm{N}$ apoleon himself suddenly appears out of the nothingness, and now it is impossible to make him disappear. The eye that has once seen him now al ways sees him with anxious necessity. It is the same with Socrates' replies. As one sees the trees, so one hears his discourse; as the trees are trees, so his words mean exactly what they sound like. There is not a single syllable to give any hint of another interpretation, just as there is not a single brush stroke to suggest $\mathrm{N}$ apoleon. Yet it is this em pty space, this nothingness, that conceals what is most important ${ }^{3}$.

We are, indeed, dealing with death here! Kierkegaard describes a picture of $\mathrm{N}$ apoleon's grave, where the figure of $\mathrm{N}$ apoleon is outlined by two trees that grow upon it. T his figuration K ierkegaard turns into a simile representing socratic irony. A picture of this kind, which "hides" an image in such a 
manner, belongs to a genre known as the puzzle picture. The D anish word for a picture like that is fikserbillede, which connotes a picture (billede) which apparently fixes (fikserer) something. At Kierkegaard's time of writing, however, the meaning of the verb fiksere was "to fool". This meaning was, via German, derived from the latin verbs fixare, to fix, and vexare, to disturb, nag or irritate. Thus, this now obsolete $D$ anish verb implies that you are fooled by an irritating something which fixes you - Got you!

The picture of $\mathrm{N}$ apoleon's grave, an engraving which was quite popular at K ierkegaard's time, is furthermore fashioned in the style of a baroque emblem 4 . Its heading: «N apoleon», occupies the position of an inscriptio. But the subscriptio: «walking on his grave», is just a continuation of this heading. Still, a certain equivocation is evidently at work in this example of the modus operandi of irony; the picture fixes you, it fools and immobilizes you, yet $\mathrm{N}$ apoleon is very much on the move as he haunts the pictura, his depicted grave - a ghostly affair, indeed.

According to K ierkegaard, this ghost all of a sudden appears out of nothingness. But this is a deceptive way of describing what happens. $\mathrm{N}$ apoleon can hardly be said to make a full-blown appearance, since his image is only neg atively defined by the stems of the trees in the picture ${ }^{5}$. Rather, it is the trees which assist nothingness in obtaining positive significance. This, however, means that the trees are no longer just trees, just like Socrates' words simultaneously mean and do not mean what they say. M imetic description is there fore no longer to be trusted. We have to face up to the fact that the signifier might signify something else besides what it manifestly signifies ${ }^{6}$. And this is a potentially deadly state of affairs; since it is no longer possible to speak by the card, equivocation can at any time undo us.

So the one that has discovered $\mathrm{N}$ apoleon is in fact - fixed, because he from then on sees him always «with anxious necessity». Just like the one who has discovered the abyss of negativity at work in the discourse of Socrates can never again rest assured that any discourse is as straightforward as it appears to be. W hat Kierkegaard's example exemplifies is thus a fall; a fall into that grave of language opened up by the disjunction between signifier and signified. Is this a fall in the theological sense of the term, then?

In order to answer this question, I will briefly examine how Vigilius $\mathrm{H}$ aufniensis actually understands the myth of the Fall in The Concept of

4. A baroque emblem consists of a picture, the pictura, a heading or title, the inscriptio, and a small text written below the picture, the subscriptio. In a genuine baroque emblem the subscriptio is a moral interpretation of the pictura.

5. Here, one should remember that Kierkegaard, in agreement with $\mathrm{H}$ egel, defines irony as «absolute unending negati vity». T his is especially interesting because Ki ierkegaard presents irony as the very condition of subjectivity - which might be a little more difficult for Hegel to accept, since the negativity of irony will then become an obstacle to the succesfiul Aufhebung of subjectivity and objectivity.

6. The problem of irony is always a problem of a 'besides', of something which is a-topical, which is not in the place or position that it ought to be. 
Anxiety. This myth, of course, is a narrative which informs us how sin came into this world. N ow, according to $\mathrm{H}$ aufniensis, the whole content of this narrative «is really concentrated in one statement: Sin came into the world by a $\sin { }^{7}$. Sin, in other words, has no previous conditions, it posits itself in a tautological fashion. O riginal sin is its own origin. Asis evident from $\mathrm{H}$ aufniensis' reading of the myth of the Fall, this means that sin more than anything else resembles or is synonymous with-language. $\mathrm{H}$ aufniensis reads as follows:

The aspect of the myth which first of all catches his attention is the paradoxical fact that Adam is supposed to understand G od's warning that he shall die if he eats from the tree before he has actually done so. As long as Adam is in a state of innocence such a warning seems meaningless, since he cannot have any idea whatsoever about what death is. $\mathrm{H}$ aufniensis tries to solve the problem by pointing out that:

The imperfection in the narrative - how it could have occured to anyone to say to Adam what he essentially could not understand - is eliminated if we bear in mind that the speaker is language, and also that it is Adam himself who speaks. (ibid., p. 47)

\section{And in a footnote to this passage he further adds that:}

If one were to say that it then becomes a question of how the first man learned to speak, I would answer that this is very true, but also that the question lies be yond the scope of the present investigation [... ]. But this much is certain, that it will not do to represent man himself as the inventor of language. (ibid., p. 47)

The narrator of the myth of the Fall, $\mathrm{H}$ aufniensis says, is language itself. And the «imperfection» - or paradox - of this myth stems from fact that language is unable to explain how it leapt into this world; die Sprache spricht, but no matter how much it talks, this one thing remains that it cannot tell us. The origin of language can thus never become an object of knowledge. Even if language simply originates as language posits itself, language effectively effaces this positing. All we can rest assured of, according to $\mathrm{H}$ aufniensis (and $\mathrm{H}$ amann and Walter Benjamin, for example, would agree), is that language is no invention of ours.

Still, language makes it possible for each individual to posit his specific individuality - but that of course means that the origin of such an individuality is also unknowable. M oreoever, such an individuality, as $\mathrm{H}$ egel, too, points out, is simultaneously erased because language, which constitutes das Allgemeine, is universal or general ${ }^{8}$. It follows that language is the stranger with-

7. I quote from Reidar Thomte's translation, Princeton, N ew Jersey, 1980, p. 32.

8. Cf. § 20-24 in the first volume of Enzyklopädie der philosophischen Wissenschaften and the passage «D ie sinnliche $G$ ewißheit oder das D iese und das M einen» in the initial chapter on 'Bewusstsein' in Phänomenologie des G eistes. Kierkegaard confronts the problem of the individual vis-a-vis das All gemeine in Fear and Trembling. 
in, an otherness which prevents the individual from coinciding with itself, because language only permits the self to posit itself as something other than itself. Language is at once the cradle and the grave of the autonomous subject.

This equivocal Abgrund, this lack of ground, in D enmark as well as elsewhere, is the hidden source of the anxiety which $\mathrm{H}$ aufniensis conceptualises. Just like $\mathrm{N}$ apoleon lurks between the trees, this source occupies the space between the lines of every page written by our watchman. And once one has become aware of this fact, one necessarily remains anxiously aware of it. In short, The Concept of Anxi ety produces anxiety, because it exemplifies the linguistic grave outlined above.

D ue to the nature of language, one is thus confronted with a tautological state of affairs in The Concept of Anxiety. But that would not at all surprise the sexton of $\mathrm{H}$ amlet:

$\begin{array}{ll}\text { H AM LET. } & \text { H ow came he mad? } \\ \text { FIRST CLOWN. } & \text { Very strangely, they say. } \\ \text { HAM LET. } & \text { H ow strangely? } \\ \text { FIRST CLOWN. } & \text { Faith, e'en with losing his wits. }\end{array}$

And ever since the Fall, according to the sexton of Copenhagen, Søren Kierkegaard, we are all of us inhabitants of this grave of language. And that indeed means that we are held hostage by tautology; in order to get out of our linguistic grave, all we can do is start digging ${ }^{9}$.

O r maybe K ierkegaard would like to persuade his reader that another way out of this predicament is relating oneself to God. Tautlogy, at any rate, is another equivocal concept in Kierkegaard: in a journal entry from 1852 which carries the title «| Am W ho I Am», thus referring to the fact that God posits himself as a perfect tautology, he writes: «As everywhere else, here also the highest and the lowest have a similarity, for tautology is the lowest kind of communication, is rubbish - and tautology again is infinitely the highest; in this case, then, anything other than tautology would be rubbish»10.

- N 0 more rubbish, then, let us henceforth call a spade a spade!

9. I have written a longer article about irony, allegory, and tautology in The Concept of I rony and The C oncept of Anxiety, «Breaking the Seals of Slumber», which has been published in Kierkegaard Studies Yearbook 1997 (Berlin \& N ew York 1998). Other texts by Kierkegaard in which his negative conception of language is expressed are JohannesClimacus De 0 mnibusdubitandum est and Climacus' Conduding unscientific Postscript, especially the long section on the style of the subjective thinker, which makes it clear that it is this negativity which constitutes the amorous relationship between the subjective thinker and language.

10. I quote from the $\mathrm{H}$ ongs' translation in volume 4 of Journalsand Papers 1-6, Bloomington and London, 1967-1978, no. 4898. 